\title{
PENENTUAN PREMI ASURANSI JIWA DWIGUNA DENGAN HUKUM DE MOIVRE DAN HUKUM GOMPERTZ
}

\author{
WULAN SYAFTIRA, RIRI LESTARI, YANITA \\ Program Studi Matematika, \\ Fakultas Matematika dan Ilmu Pengetahuan Alam, Universitas Andalas, \\ Kampus UNAND Limau Manis Padang, Indonesia, \\ email : wulansyaftira@gmail.com
}

\begin{abstract}
Abstrak. Penelitian ini bertujuan untuk menentukan premi asuransi jiwa dwiguna. Premi yang akan ditentukan merupakan premi tahunan. Premi tahunan dipengaruhi oleh premi tunggal dan nilai tunai anuitas hidup awal. Perhitungan premi pada asuransi jiwa dwiguna disini menggunakan hukum De Moivre dan hukum Gompertz. Hukum De Moivre merupakan salah satu hukum mortalita yang diperoleh dari distribusi seragam (uniform). Hukum Gompertz berasal dari distribusi Gompertz dan dipengaruhi oleh konstanta Gompertz. Premi asuransi jiwa dwiguna yang diperoleh dengan menggunakan hukum De Moivre lebih kecil jika dibandingkan dengan premi asuransi jiwa dwiguna yang diperoleh dengan hukum Gompertz.
\end{abstract}

Kata Kunci: Asuransi dwiguna, anuitas, premi, hukum De Moivre, hukum Gompertz

\section{Pendahuluan}

Asuransi jiwa merupakan suatu asuransi yang memberikan pembayaran sejumlah uang tertentu atas kematian tertanggung kepada ahli waris atau orang yang berhak menerimanya sesuai dengan ketentuan dalam polis asuransi. Sejumlah uang yang dibayarkan kepada tertanggung tersebut disebut santunan. Salah satu jenis asuransi jiwa adalah asuransi jiwa dwiguna. Asuransi jiwa dwiguna adalah asuransi jiwa yang dalam maupun saat berakhirnya masa pertanggungan kepada pemegang polis, baik meninggal maupun bertahan hidup akan dibayarkan uang pertanggungan. Peserta asuransi mempunyai kewajiban membayar premi kepada perusahaan asuransi. Besarnya premi yang dibayarkan dipengaruhi oleh peluang hidup, tingkat bunga dan biaya lainnya. Salah satu metode perhitungan premi adalah dengan pendekatan hukum mortalitas De Moivre dan Gompertz.

Hukum De Moivre ditemukan oleh seorang ilmuan yang bernama Abraham De Moivre. Hukum ini diperoleh dari distribusi seragam yang menggunakan interval $[0, \omega]$ dengan 0 merupakan usia seseorang yang baru lahir dan $\omega$ merupakan usia maksimal seseorang, sehingga fungsi kepadatan probabilitasnya adalah $f(x)=\frac{1}{\omega}$. Hukum Gompertz didefinisikan oleh B. Gompertz pada tahun 1825 yang pada dasarnya digunakan untuk menentukan percepatan mortalita. Namun dari fungsi kepadatan peluangnya dapat juga ditentukan peluang hidup dan peluang meninggal dengan hukum Gompertz. 


\section{Nilai Tunai Anuitas Dan Premi Asuransi Jiwa Dwiguna Dengan} Hukum De Moivre

Anuitas adalah suatu rangkaian pembayaran dalam jumlah tertentu yang dilakukan secara berkala pada jangka waktu tertentu secara berkelanjutan. Anuitas hidup adalah anuitas yang pembayaran dilakukan tergantung hidup dan matinya seseorang [1]. Jika pembayaran dilakukan di awal periode maka disebut anuitas hidup awal. Hukum De Moivre diperoleh dari fungsi kepadatan peluang distribusi seragam, yaitu

$$
f(x)=\frac{1}{\omega}, 0 \leq x \leq \omega .
$$

Berdasarkan persamaan (2.1), peluang meninggal dari seseorang yang berusia $x$ tahun akan meninggal dalam usia $x+t$ tahun adalah

$$
{ }_{t} q_{x}=\frac{t}{\omega-x} .
$$

Berdasarkan persamaan (2.2), peluang hidup dari seseorang yang berusia $x$ tahun akan hidup pada usia $x+t$ tahun adalah

$$
{ }_{t} p_{x}=\frac{\omega-x-t}{\omega-x} .
$$

Nilai tunai anuitas hidup awal berjangka untuk seseorang berusia $x$ tahun dengan jangka pertanggungan $n$ tahun, dinyatakan dengan [2]

$$
\ddot{a}_{x: \bar{n} \mid}=\frac{1-A_{x: \bar{n} \mid}}{i v},
$$

atau dalam bentuk lain dapat dinyatakan dengan

$$
\ddot{a}_{x: \bar{n} \mid}=\sum_{t=0}^{n-1} v^{t}{ }_{t} p_{x} .
$$

Notasi $A_{x: \bar{n} \mid}$ pada persamaan (2.4) merupakan premi tunggal bersih asuransi jiwa dwiguna, dapat dinyatakan dengan

$$
A_{x: \bar{n} \mid}=\sum_{t=0}^{n-1} v^{t+1}{ }_{t} \mid q_{x}+v^{n}{ }_{n} p_{x} .
$$

dimana ${ }_{t} \mid q_{x}$ merupakan peluang seseorang berusia $x$ akan bertahan hidup hingga $t$ tahun dan akan meninggal 1 tahun berikutnya dinyatakan dengan

$$
{ }_{t} \mid q_{x}={ }_{t} p_{x} q_{x+t} .
$$

Pada persamaan (2.6), dengan menggunakan peluang hidup dan peluang meninggal hukum De Moivre diperoleh premi tunggal bersih asuransi jiwa dwiguna sebagai berikut:

$$
A_{x: \bar{n} \mid}=\frac{v\left(\ddot{a}_{\bar{n} \mid}\right)+v^{n}(\omega-x-n)}{(\omega-x)} .
$$


Kemudian dengan mensubstitusikan persamaan (2.8) ke persamaan (2.4), nilai tunai anuitas hidup awal berjangka tahun dengan hukum De Moivre dinyatakan dengan

$$
\ddot{a}_{x: \bar{n} \mid}=\frac{i v\left(\ddot{a}_{\bar{n} \mid}\right)(\omega-x)-v\left(\ddot{a}_{\bar{n} \mid}\right)+v^{n} n}{i v(\omega-x)} .
$$

Premi tahunan asuransi jiwa dwiguna merupakan premi yang dibayarkan setiap tahunnya oleh peserta asuransi ke perusahaan asuransi selama jangka waktu pertanggungan. Pembayaran premi akan berakhir apabila terjadi kematian ataupun kontrak berakhir. Besarnya premi tahunan untuk seseorang berusia $x$ tahun dengan jangka pertanggungan $n$ tahun, dinyatakan dengan [2]

$$
P_{x: \bar{n} \mid}=R \frac{A_{x: \bar{n} \mid}}{\ddot{a}_{x: \bar{n} \mid}} .
$$

Substitusikan persamaan (2.8) dan persamaan (2.9) ke persamaan (2.10) sehingga diperoleh premi tahunan dengan hukum De Moivre yaitu

$$
P_{x: \bar{n} \mid}=R \frac{\frac{v\left(\ddot{a}_{\bar{n} \mid}\right)+v^{n}(\omega-x-n)}{(\omega-x)}}{\frac{i v\left(\ddot{a}_{\bar{n} \mid}\right)(\omega-x)-v\left(\ddot{a}_{\bar{n} \mid}\right)+v^{n} n}{i v(\omega-x)}} .
$$

\section{Nilai Tunai Anuitas dan Premi Asuransi Jiwa Dwiguna dengan Hukum Gompertz}

Percepatan mortalita dari peserta asuransi yang berusia $x$ tahun berdasarkan hukum Gompertz dinyatakan dengan [2]

$$
\mu_{x}=B c^{x}, B \geq 0, c \geq 1, x \geq 0,
$$

dengan B dan c adalah konstanta Gompertz.

Distribusi Gompertz $G(x \mid \mu, \sigma)$ dengan rata-rata $\mu$ dan standart deviasi $\sigma$ didefinisikan sebagai:

$$
G(x \mid \mu, \sigma)=W\left(\frac{x-a}{b}\right)
$$

dengan $W(x)=1-e^{-e^{x}}$ dan a, b merupakan konstanta. Konstanta $a$ dan $b$ haruslah memenuhi

$$
\sigma=\frac{\pi}{6} b, \pi=3,14, \mu=a-b \gamma
$$

Distribusi $G(x \mid \mu, \sigma)$ Gompertz dapat dinyatakan dalam bentuk

$$
G(x \mid \mu, \sigma)=1-g^{c^{x}}
$$

dengan $g=e^{-e^{\frac{a}{b}}}$ dan $c=e^{\frac{1}{b}}$. Berdasarkan persamaan (3.1), diperoleh peluang hidup dari seseorang yang berusia $x$ tahun akan hidup $t$ tahun lagi yaitu

$$
{ }_{t} p_{x}=g^{c^{x\left(c^{t}-1\right)}} .
$$

Substitusikan persamaan (3.4) ke persamaan (2.5) sehingga nilai tunai anuitas hidup awal berjangka $x$ tahun dengan hukum Gompertz dinyatakan dengan

$$
\ddot{a}_{x: \bar{n} \mid}=\sum_{t=0}^{n-1} v^{t} g^{c^{x\left(c^{t}-1\right)}} .
$$


Selanjutnya substitusikan persamaan (3.5) ke persamaan (2.4) sehingga diperoleh

$$
A_{x: \bar{n} \mid}=1-i v \sum_{t=0}^{n-1} v^{t} g^{c^{x\left(c^{t}-1\right)}} .
$$

Substitusikan persamaan (3.5) dan persamaan (3.6) ke persamaan (2.10) sehingga diperoleh premi tahunan dengan hukum Gompertz yaitu

$$
P_{x: \bar{n} \mid}=R \frac{1-i v \sum_{t=0}^{n-1} v^{t} g^{c^{x\left(c^{t}-1\right)}}}{\sum_{t=0}^{n-1} v^{t} g^{c^{x\left(c^{t}-1\right)}}} .
$$

\section{Ilustrasi Kasus}

Pak Rano seorang karyawan swasta yang saat ini berusia 35 tahun mengikuti asuransi jiwa dwiguna dengan polis selama 30 tahun. Jika diasumsikan umur maksimal adalah 100 tahun (dari tabel mortalitas Indonesia 1999) dan santunan yang akan diterima adalah sebesar Rp 50.000.000,-. Besar premi asuransi jiwa dwiguna dengan hukum De Moivre dan hukum Gompertz dapat ditentukan sebagai berikut: Dari ilustrasi diketahui $x=35, n=30, R=\mathrm{Rp} 50.000 .000,-\omega=100$ dengan tingkat suku bunga $i=0,025$, dan $v=0,975609756$. Premi asuransi jiwa dwiguna dengan hukum De Moivre adalah:

$$
\begin{aligned}
P_{35: \overline{30} \mid}=R \frac{v\left(\ddot{a}_{\overline{30} \mid}\right)+v^{30}(100-35-30)}{(100-35)} & \frac{1-v\left(\ddot{a}_{\overline{30} \mid}\right)(100-35)-v\left(\ddot{a}_{\overline{30} \mid}\right)+v^{30} 30}{i v(100-35)} \\
= & R p 50.000 .000 \frac{0,5787121}{17,27280385}=R p 1.675 .211,81 .
\end{aligned}
$$

Berdasarkan Tabel Mortalita Indonesia (TMI) 1999 untuk laki-laki, usia rata-rata $\mu=50$ dan standart deviasinya adalah $\sigma=29,15475947$ sehingga diperoleh nilai konstanta Gompertz yaitu $g=0,939658079$ dan $c=1,04497295$. Premi asuransi jiwa dwiguna dengan hukum Gompertz adalah:

$$
\begin{aligned}
P_{35: \overline{30} \mid} & =R \frac{1-i v \sum_{t=0}^{29} v^{t} g^{c^{35\left(c^{t}-1\right)}}}{\sum_{t=0}^{29} v^{t} g^{c^{35\left(c^{t}-1\right)}}} \\
& =R p 50.000 .000 \frac{0,59112878}{16,76372001}=R p 1.763 .119,34
\end{aligned}
$$

Selanjutnya akan diperlihatkan besarnya premi berdasarkan hukum De Moivre dan hukum Gompertz dengan kasus diatas, untuk lama masa pertanggungan $(n)$, usia tertanggung $(x)$ dan santunan $(R)$ yang berbeda sebagai perbandingan. Besar premi jika dimisalkan lama masa pertanggungan 15-30 tahun dapat dilihat pada tabel di Gambar 1. Besar premi jika usia Pak Rano dari 30-40 tahun dapat dilihat pada tabel di Gambar 2. Besar premi jika dimisalkan besar santunan Rp 10.000.000,- Rp 50.000.000,- dan Rp 100.000.000,- dapat dilihat pada tabel di Gambar 3.

Berdasarkan ketiga tabel tersebut, dapat disimpulkan bahwa premi asuransi jiwa dwiguna yang diperoleh dengan hukum Gompertz lebih besar daripada premi asuransi jiwa dwiguna yang diperoleh dengan hukum De Moivre. Jika semakin lama 


\begin{tabular}{|c|c|c|}
\hline$n$ (tahun & Premi Hukum De Moivre & Premi Hukum Gompertz \\
\hline 15 & 3161078,24 & 3359605,91 \\
\hline 16 & 2966299,73 & 3138955,68 \\
\hline 17 & 2795609,26 & 2947719,69 \\
\hline 18 & 2645002.05 & 2780754,55 \\
\hline 19 & 2511316,30 & 2634045,51 \\
\hline 20 & 2392022,44 & 2504425,56 \\
\hline 21 & 2285072,59 & 2389360,23 \\
\hline 22 & 2188791,07 & 2286796,82 \\
\hline 23 & 2101793,49 & 2195054,72 \\
\hline 24 & 2022926,08 & 2112744,34 \\
\hline 25 & 1951219,51 & 2038706,35 \\
\hline 26 & 1885853,46 & 1971965,38 \\
\hline 27 & 1826129,00 & 1911694,54 \\
\hline 28 & 1771446,92 & 1857187,68 \\
\hline 29 & 1721290,50 & 1807837,72 \\
\hline 30 & 1675211,81 & 1763119,34 \\
\hline
\end{tabular}

Gambar 1. Besar Premi (dalam Rupiah) Menggunakan Hukum De Moivre dan Hukum Gompertz dengan Lama Masa Pertanggungan 15-30 tahun

\begin{tabular}{|c|c|c|}
\hline$x$ (tahun & Premi Hukum De Moivre & Premi Hukum Gompertz \\
\hline 30 & 1626016,26 & 1642540,42 \\
\hline 31 & 1635156,73 & 1664504,39 \\
\hline 32 & 1644627,59 & 1687494,54 \\
\hline 33 & 1654447,06 & 1711559,47 \\
\hline 34 & 1664634,77 & 1736750,00 \\
\hline 35 & 1675211,81 & 1763119,34 \\
\hline 36 & 1686200,95 & 1790723,13 \\
\hline 37 & 1697626,75 & 1819619,56 \\
\hline 38 & 1709515,75 & 1849869,44 \\
\hline 39 & 1721896,72 & 1881536,32 \\
\hline 40 & 1734800,83 & 1914686,56 \\
\hline
\end{tabular}

Gambar 2. Besar Premi (dalam Rupiah) Menggunakan Hukum De Moivre dan Hukum Gompertz dengan Usia Tertanggung 30-40 tahun

\begin{tabular}{|c|c|c|}
\hline$R$ & Premi Hukum De Moivre & Premi Hukum Gompertz \\
\hline$R p 10.000 .000,-$ & 335042,363 & 352623,86 \\
\hline$R p 50.000 .000,-$ & 1675211,81 & 1763119,34 \\
\hline$R p 100.000 .000,-$ & 3350423,63 & 3526238,69 \\
\hline
\end{tabular}

Gambar 3. Besar Premi (dalam Rupiah) Menggunakan Hukum De moivre dan Hukum Gompertz dengan Besar Santunan Rp 10.000.000,- Rp 50.000.000,- dan Rp 100.000.000,-.

masa pertanggungan maka besar premi yang harus dibayarkan semakin kecil, jika semakin tinggi usia tertanggung saat mengikuti asuransi maka premi yang harus dibayarkan semakin besar dan jika besar santunan yang diharapkan lebih besar maka premi yang harus dibayarkan semakin besar.

\section{Kesimpulan}

Premi dipengaruhi oleh peluang hidup, tingkat suku bunga dan biaya lainnya. Premi asuransi jiwa dwiguna yang diperoleh dengan hukum Gompertz lebih besar dari pada premi asuransi jiwa dwiguna yang diperoleh dengan hukum De Moivre. Pada 
kasus pak Rano, jika semakin lama masa pertanggungan maka besar premi yang harus dibayarkan semakin kecil, jika semakin tinggi usia tertanggung saat mengikuti asuransi maka premi yang harus dibayarkan semakin besar dan jika besar santunan yang diharapkan lebih besar maka premi yang harus dibayarkan semakin besar.

\section{Daftar Pustaka}

[1] Futami, T. 1993. Matematika Asuransi Jiwa Bagian I. Incorporated Foundation Oriental Life Insurance Cultural Development Center, Tokyo

[2] Bowers, N L., Gerber, H.U., Hickman,J.C., Jones, D.A., dan Nesbitt, CJ. 1997. Actuarial Mathematics. Illinois: The Society of Actuaries. 